\begin{tabular}{l|l}
$\mathbf{m} \boldsymbol{m}$ & south \\
asia
\end{tabular}

samaj multidisciplinary

uilu academic
South Asia Multidisciplinary Academic Journal

$14 \mid 2016$

Environment Politics in Urban India: Citizenship, Knowledges and Urban Political Ecologies

\title{
Of Slums and Politics in Puri, Odisha: The Localisation of the Slum-Free Cities Mission in the Temple City
}

\section{Andrea Hagn}

\section{(2) OpenEdition}

\section{Journals}

Electronic version

URL: http://journals.openedition.org/samaj/4226

DOI: $10.4000 /$ samaj.4226

ISSN: 1960-6060

Publisher

Association pour la recherche sur l'Asie du Sud (ARAS)

Electronic reference

Andrea Hagn, « Of Slums and Politics in Puri, Odisha: The Localisation of the Slum-Free Cities Mission in the Temple City », South Asia Multidisciplinary Academic Journal [Online], 14 | 2016, Online since, connection on 30 April 2019. URL : http://journals.openedition.org/samaj/4226 ; DOI : 10.4000/ samaj.4226

This text was automatically generated on 30 April 2019.

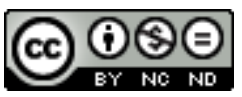

This work is licensed under a Creative Commons Attribution-NonCommercial-NoDerivatives 4.0 International License. 


\title{
Of Slums and Politics in Puri, Odisha: The Localisation of the Slum-Free Cities Mission in the Temple City
}

\author{
Andrea Hagn
}

\section{AUTHOR'S NOTE}

This paper results from my doctoral research at ETH Wohnforum-ETH CASE, ETH Zürich, Department of Architecture. The dissertation, which is in its concluding stage, is concerned with the nature of contemporary urban development in India and the role of urban policy therein. In particular, the emphasis is on the role of slum re-development in remaking Indian medium-sized cities. The first three years of the project were funded by a Sawiris Scholarship (now referred to as E4D Doctoral Scholarships, see https:// www.ethz.ch/en/the-eth-zurich/global/funding-opportunities/research-fordevelopment/sawiris-scholarships/e4d-doctoral-scholarships.html). The author is grateful to all who supported her throughout the research journey, in many different ways, both in India and Switzerland; however, most explicitly, to Professor Swapna Banerjee-Guha.

\section{Introduction}

1 This paper grew out of my scholarly interest in how the "urban local process" of a smaller city $^{1}$ is connected to India's "larger urban process" by means of slum re-development policy (see author's notes). Contemporary urban development in India is driven by the elite aspiration to develop cities as global or world cities (Banerjee-Guha 2010; 
Dupont 2011; Goldman 2011; Roy 2014; Roy 2011a). While Indian cities are facing a range of complex challenges and suffer from diverse problems, urban renewal and the associated ideology of "decentralisation-privatisation-participation" have become defining elements in the contemporary mode of urban development (Tawa Lama-Rewal and Zérah 2011). By and large big-city policy, India's urban policy not only reflects these ideologies but also plays a critical role in their materialisation (Knox 2009). Thereby, it is further reinforcing the existing economic and political dominance of large cities (Banerjee-Guha 2010; Banerjee-Guha 2002). Concurrently, the United Progressive Alliance (UPA) government's 2005 Jawaharlal Nehru National Urban Renewal Mission, short JNNURM, also pulled smaller cities into the process of "neoliberalising the urban" (Banerjee-Guha 2009). ${ }^{2}$ This is not to say that these smaller Mission cities and towns were selected coincidentally. Irrespective of their actual size, they all are significant urban configurations of political, economic, and often religious relevance.

2 While India's large cities have experienced the pressure of globalisation and liberalisation for some time, there is little knowledge about how smaller cities cope with the contemporary mode of urban development (Véron 2010). Generally, smaller cities are disadvantaged in the context of growing inter-urban and intra-urban inequality, and inter-urban competition (Banerjee-Guha 2009; Bell and Jayne 2006; Kundu 2001; UNFPA 2007; Véron 2010). Addressing this blind spot in research, which also reflects the big-city bias, this paper focuses on the smaller Mission city of Puri, Odisha. This famous temple city is situated in a less urbanised state of India by the Bay of Bengal. In 2011, it had a population of 201,026 inhabitants (GOI 2011a).

3 An important component in the process of urban restructuring is the strategy of the Indian state towards re-developing "slums." This focus on "slums" is not new (e.g. Sivaramakrishnan 2012). Slum improvement has been an integrative part of British colonial town planning (Gooptu 2001; Home 1997; Huchzermeyer 2014). Also postIndependence, the various governments addressed slum improvement and clearance through the respective Five Year Plans (Batra 2009). This legacy has to be taken into account when analysing, as this paper does, the role of slum re-development in smaller Indian cities today.

4 The signs are that slum redevelopment under the guise of inclusive planning serves as a means to recapture valuable urban land for often speculative real-estate development (Arabindoo 2011; Baviskar 2012; Kundu 2013; Roy 2014). While the respective component of JNNURM, the Sub-Mission on Basic Services to the Urban Poor (BSUP), targeted only a small section of "slums" in 63 cities, the UPA government in 2009 launched a dedicated flagship scheme: Rajiv Awas Yojana (RAY) or the Slum-Free Cities Mission (Mathur 2009, GOI 2009). It was targeted to re-develop, relocate and rehabilitate all slums in 250 cities: moving from the "ad hoc project-based approach of JNNURM to a whole city, all slums and whole slum approach" (Selja 2011:6). While JNNURM covered two cities in Odisha (Bhubaneswar and Puri), the Slum-Free Cities Mission was initiated in six cities in the state. Puri is one of these. ${ }^{3}$ For the purpose of this Special Issue, I focus exclusively on the Slum-Free Cities Mission in the temple city of Puri.

5 Before continuing, I deem it necessary to emphasise that, despite its global popularity today, the term "slum" as such is deeply problematic (Arabindoo 2011; Gilbert 2009; Gilbert 2007; Huchzermeyer 2014; Roy 2014; Roy 2011b; Seabrook 2009). In the Anglophone world, it is a negatively connoted label that has been historically associated with unsanitary (disease-prone), sub-standard and deteriorating (inadequate) housing 
and living conditions (Huchzermeyer 2014). It was first used in the second decade of the nineteenth century in industrialising Britain (Seabrook 2009; Young 2011). While its "inglorious associations" are "inappropriate to poor urban settlements of Dhaka, Mumbai or Lagos," as well as the medium city of Puri, this legacy is still tangible in the contemporary definition of and perspective on "slum" in India (Arabindoo 2011:638; Seabrook 2009; see also Batra 2009; Bhan 2009; Ghertner 2012; Young 2011). The main problem however is twofold.

6 Firstly, "slums" have become a synonym for urban poverty and are used by many researchers and governments to measure and plan for eradicating urban poverty (Arabindoo 2011:637; also Roy 2014:142). However, neither are all slum dwellers poor nor do all the poor live in slums (Risbud 2009). By making Indian cities free of the spatial configurations categorised as slums, poverty will thus not be ended (Arabindoo 2011:638). Secondly, and this also became clear in my study of Puri, formal recognition as a "slum" has become the ticket for poor communities to negotiate not only access to basic services and other state resources, but also their presence in the city (Arabindoo 2011:642).

Being listed as a "slum" proved to be decisive for poor communities in Puri in becoming eligible for the Slum-Free Cities Mission. As the Mission is about assigning property rights to the urban poor, it is about nothing less than the hope to become full-fledged urban citizens (Roy 2014:143). With its focus on the localisation of the Slum-Free Cities Mission in Puri, this paper thus contributes to this special issue, focussed as it is on exploring the ways in which the urban environment, urban environmental practices and politics serve as a crucible for negotiations around urban citizenship.

8 The main emphasis of this paper, however, is not on list-making as such. My study in Puri was guided by the question: What makes poor urban communities successful in accessing slum improvement schemes? Therefore, I carried out research in three blocks between 2011 and 2013. This research included qualitative interviews with different stakeholders, including members of several RAY Management Committees. ${ }^{4}$ However, I had no direct access to the actual situations of list-making, surveying and mapping, or political negotiation.

9 Against this background, this paper focuses on two elements in the process of preparing the Slum-Free City Plan of Puri: the list of eligible slums, and RAY Management Committees. The paper addresses the following three inter-linked questions: How is the Slum-Free Cities Mission localised in the particular urban situation of the medium-sized city of Puri (Roy 2014:138)? Which actors are involved in this process, and how? And what effects does the Mission have on Puri as urban environment and, in particular, the urban poor?

10 Following this introduction, the second section highlights key issues pertaining to the Slum-Free Cities Mission. Against this background, it presents the context and actors of the implementation of the Mission in Puri and Odisha. The third section briefly introduces the historical specificity of the temple city, pertaining to land ownership as a relevant context to the local meaning of "slum" and the problem of slum redevelopment. The forth section explores how the Mission is actually localised in Puri. Therefore, it focuses on two selected elements in this process: the list of eligible slums, and RAY Management Committees. Finally, the fifth section summarises the main findings in order to answer the three guiding research questions of this paper. 


\section{Making Puri slum-free}

11 The global urban politics of slum upgrading, with its "vision of financialisation: the ambition to link the residents and infrastructures of slums to capital markets," has long been decisive for the slum improvement efforts of many countries including India (Jones 2012:777). The Slum-Free Cities Mission similarly is the product of an era characterised both by "a rearrangement of the established geographies of development and underdevelopment ... and a new global commitment to poverty alleviation" (Roy 2014:139). This commitment, so Roy, is embodied also in the Millennium Development Goals, which signify a new philosophy of human development, "a new global social contract that makes possible the idea of 'the end of poverty"' (Sachs 2005, in Roy 2014:139). It somewhat breaks with the earlier "market fundamentalism" (Stiglitz 2003, in Roy 2014:139). Nevertheless, while "India has the largest concentration of poor of any country," its new vision of inclusive growth remains clearly market-oriented (Datt and Ravaillion 2010:59, in Roy 2014:139): "It is premised on the argument that the benefits of economic growth can be extended to 'currently excluded sections,' often through reforms in 'governance and accountability"' (Deloitte 2011:3, in Roy 2014:139; Roy 2010; see also Jones 2012).

\section{Contradictions of the project of inclusive growth}

12 The interest in bringing the currently excluded into the market economy, however, is not based on philanthropy alone. It reflects the fear of urban elites that India's economic growth suffers if cities continue to develop as highly divided and contested socio-spatial entities (Sahoo 2016; McKinsey 2010). In 2012, the government recognised that the last decade of faster economic growth has "raised the expectations of all sections, especially those who have benefited less. Our people are now much more aware of what is possible, and they will settle for no less" (GOI 2012, in Roy 2014:137). Apart from economic concerns, the new emphasis on inclusive urban growth thus has been motivated by growing fears of social unrest in Indian cities. In 2013, the government therefore declared that urban planning must address the needs of the poor "in terms of ... spaces of livelihood, living and working" (GOI 2013). Not only does the Slum-Free Cities Mission give "centrality to the slum in the making of urban futures. It also recognises [for the first time] the exclusionary nature of Indian urbanisation and urban planning" (Roy 2014:142).

13 It is against this background that the Slum-Free Cities Mission, announced in 2009 and formally launched in 2011, is discussed as a paradigmatic shift towards the integration of "slums" and "inclusive growth" (Kundu 2013; Roy 2014). It is celebrated as "a new deal for the urban poor" (Mathur 2009). Roy further suggests that the Slum-Free Cities Mission "signals a new welfare regime. It is the urban counterpart to India's rural welfare policies" (2014:142). The Mission "is an expression of a right to shelter we have refused to give to our fellow citizens even as information, education and health have been won" (Bhan 2011, in Roy 2014:142).

14 Kundu similarly notes that the objective of the Mission is to enable "poor urban families to realise their dream of owning a house that has a proper land title and access to basic amenities" (2013:15). The new mode of slum re-development thus "seeks to transform slum land into urban assets. To do so it conjures up instruments of reform already 
introduced by the JNNURM" (Roy 2014:143). Nevertheless, the problem of making slum land property is enormous. It involves transforming "the complex ambiguities of informal property regimes into cadastral property and even more boldly into urban assets with globally legible value" (Roy 2014:137-38; also Raman 2015).

Amidst the enthusiasm, it is important to remember that this new emphasis on inclusive planning has been propagated after a decade of often brutal eviction drives that took place in many cities: these evictions "form part of a calculated plan to recapture valuable land for real-estate development" (Arabindoo 2011:637). The noble discourse of inclusive growth thus is paired with "the freeing up of inner-city slum-land to the speculative exuberance of private capital" (Arabindoo 2011:637; also Baviskar 2012; BanerjeeGuha 2009). The question that ultimately arises is whether the Mission really breaks with this practice and delivers on the hopes and expectations that it created (Kundu 2013). ${ }^{5} \mathrm{Or}$ whether it functions as a more tacit means to re-appropriate increasingly-valuable innercity land.

Even if the Mission propagates the credo that evictions are to be avoided and slums are to be developed on-site, too often, maintenance costs exceed the financial capacity of poor beneficiaries, in in-situ redeveloped sites as well (Kundu 2013:15). The question of affordability has not yet been sufficiently addressed (Kundu 2013:16). Many newly constructed housing units therefore remain vacant; especially in relocation sites. The reason is the lack of and/or incomplete basic infrastructure and livelihood sources (Dubbudu 2016; Bhattacharyya 2016). As a corollary, relocation is associated with the spatial reproduction of urban poverty (Coelho, Venkat and Chandrika 2012; see also Rao 2010). It is therefore no surprise that Roy (2014:138) warns: "accumulation, and even dispossession, can proceed ... also through paradigms of inclusive growth."

Kundu also critiques the tool for operationalising the Mission, the Slum-Free City Plan of Action (2013). Technically, the urban local body is to prepare this plan in consultation with concerned state government departments, technical experts, as well as resident communities (Kundu 2013:15-16). Kundu identifies two main deficits: he misses both "a reliable framework for identifying non-tenable slums and legitimate slum households that are entitled to get dwelling units"; and "a clear road map for its time bound implementation" (2013:15-16). What would be needed, so Kundu, are "clear policy directives defining the ground rules at the national and state levels ... [and] standard criteria ... proposed at the higher levels without any ambiguity and then applied in the field by taking the local context into account" (2013:16). So far, attempts to operationalise the Mission at the city level "have faced enormous problems and conflicts of interests, often leading to legal impasse." In particular, the "categories of hazardous or ecologically sensitive locations and public purpose are used to arbitrarily evict slums" (Kundu 2013:16).

Thus, while the Slum-Free Cities Mission tries to include the poor in the formal planning process, the suggested procedures for operationalisation undermine its high ambitions. It seems that, once again, "regulatory ambiguity" performs its task (Roy 2014:144; Roy 2003). It allows local powerful actors to make use of the Mission according to their very own terms. The urban local context, in other words, remains decisive for how, if at all, urban policy is implemented. Before introducing the context and actors of the implementation of the Slum-Free Cities Mission in Odisha and Puri, I must also add that the Mission was formally discontinued in May 2015 following the election of Narendra 
Modi (GOI 2015). As the only pilot project in Puri had not yet produced results, it has also not been subsumed under the new Mission on Housing for All by 2022 (GOI 2015).

\section{Local context and actors}

19 The Slum-Free Cities Mission was the third scheme addressing the urban development of the temple city. The first was the Eco-City Programme. ${ }^{6}$ In its first phase, it covered six smaller cities: Vrindavan, Puri, Ujjian, Tirupati, Kottayam, and Thanjavour (Surjan and Shaw 2008:252). In 2005, the School of Planning and Architecture in New Delhi formulated the Eco-City Development Plan for Puri (SPA 2005). Concurrently, Puri was selected for the Jawaharlal Nehru National Urban Renewal Mission (JNNURM). ${ }^{7}$ When the City Managers' Association Orissa prepared the Puri City Development Plan in 2005, it had already become clear that the Eco-City Project had failed in Puri (Surjan and Shaw 2008:257). Hoping "to make Puri a 'globally competitive' tourism and heritage city," JNNURM thus appeared as a "jackpot" to Puri's elite and local decision makers (Surjan and Shaw 2008:258; CMAO 2006). Ten years later, this ambition has transformed the urban fabric even if the City Development Plan still remains "a 'dream wish list' for the city" (Surjan and Shaw 2008:258). While the performance of JNNURM has been very poor in Odisha, none of the three initiated infrastructure projects in Puri has been completed up to date..$^{8}$ Not even the pressure leading up to the religious mega event of Nabakalebara ${ }^{9}$ in July 2015, when Puri expected over five million devotees, contributed towards completing the work. ${ }^{10}$

This pressure did, however, lead to Puri's first forced eviction. In October 2014, a section of Puri's third largest slum near Puri station was cleared although Puri Municipality did not know yet where to relocate the slum dwellers. While in December 2013, the community spoke of violent resistance, and although they were purportedly a BJD vote bank, the pressure to develop infrastructure for the festival had become paramount. ${ }^{11}$ To this day, the evicted slum dwellers have not been rehabilitated..$^{12}$ This represents a violation of the State's 2011 Slum Rehabilitation and Development Policy (GOO 2011).

21 I have to add that the government, newly elected in May 2015, not only stopped the SlumFree Cities Mission but also discontinued JNNURM. It however agreed to provide financial assistance to the ongoing project works in Puri and Bhubaneswar. This purportedly includes the slum improvement projects started in Puri under BSUP. ${ }^{13}$ When I carried out interviews in Puri in December 2013, this was not clear. Furthermore, while the urban flagship schemes of the former government were closed, Narendra Modi announced several new schemes. In January 2015 Puri was included in the new Heritage City Development and Augmentation Yojana (HRIDAY). The prospective financial assistance under HRIDAY is substantially smaller than that under JNNURM. Instead of a total investment planned of INR 1,828 crore (US\$ 456 million), the Centre now committed INR 22 crore (about US $\$ 3.5$ million) to the development of infrastructure in the city. ${ }^{14}$

Regarding the Slum-Free Cities Mission in Odisha, six cities were selected by the State government led by Naveen Patnaik in 2011: the two JNNURM Mission cities Bhubaneswar and Puri, as well as Cuttack, Berhampur, Sambalpur, and Rourkela. At the state level, the implementation of the Mission was led by a steering committee chaired by the Chief Minister and monitored by the Secretary, Department of Housing and Urban Development. As state-level nodal agency, Naveen Patnaik nominated the Bhubaneswar Development Authority. Its vice-chairman was made state-level nodal officer. ${ }^{15}$ Quite in 
contrast to the rhetoric of making India slum-free by 2022, the Centre asked the State to scale-down over-ambitious plans. ${ }^{16}$ As legislative framework, the State government also introduced the Slum Rehabilitation and Development Policy (SRDP) "Housing for all" and the Odisha Property Rights to Slum Dwellers and Prevention of New Slums Bill (GOO 2011; GOO 2012).

In Puri, the formulation of a Slum-Free City Plan was initiated in 2011. Therefore, a citylevel technical cell was set-up in 2012. It consisted of a MIS specialist, a "GIS cum Town Planning" specialist, a "Social Development cum $\mathrm{CB} / \mathrm{T}$ " specialist, and a Project/ Engineering specialist. It had three main tasks: coordination and project management; preparation and updating of data bases and maps; and slum-free city planning (SUIDL 2013:6-7). The local NGO Pragati was contracted as lead-NGO for "community mobilisation and organisation." Two other agencies were hired for the required GIS mapping and surveying of households. ${ }^{17}$ These tasks were not yet completed by December 2013. ${ }^{18}$ In November 2014 the pilot project was finally approved by the Central Sanctioning and Monitoring Committee (SUIDL 2013; GOO 2014; GOI 2015:7). The total project costs were estimated as INR 1,597.89 lakhs or USD 2.6 million (GOO 2014). Producing 384 dwelling units, the first phase of the Slum-Free Cities Mission in Puri thus would have benefited only a small share of Puri's more than 47,530 slum dwellers (GOO 2014; SUIDL 2013:14). ${ }^{19}$

The DPR further contains information on the categorisation of slums in Puri, as generated by the then on-going slum-free city planning in the city. While in 2001, Puri Municipality had listed 46 slums in the city ( 26 notified and 20 non-authorised $\left.{ }^{20}\right), 62$ of 69 identified slums were now categorised as eligible for access to the Slum-Free Cities Mission (SUIDL 2013:14-15). The 69 slums listed in the DPR were categorised as follows:

Figure 1

\begin{tabular}{|l|l|l|l|}
\hline Category & Notified slums & Unauthorised slums & Total \\
\hline Tenable & 28 & 8 & 36 \\
\hline Semi-tenable & 7 & 1 & 8 \\
\hline Untenable & 11 & 14 & 25 \\
\hline Total & 46 & 23 & 69 \\
\hline
\end{tabular}

CATEgORISATION OF SLUMS IN PURI (SOURCE: SUIDL 2013:25-26)

Of these slums, 34 slums with 3,115 households were identified as tenable sites and therefore scheduled for on-site re-development and/or incremental development. The pilot site is one of them. 25 slums with 3,659 households were identified as untenable and therefore scheduled for relocation. Further, an undefined number of households in ten more slums were to be relocated. These sites were classified as semi-tenable. In other words, more than half of Puri's slum population was now destined for resettlement (SUIDL 2013:22). In previous urban development schemes Puri Municipality could not leverage sufficient resources, which contributed to their failure (Surjan and Shaw 2008). The Slum-Free Cities Mission however faced the same severe difficulties as Puri Municipality, not only for lacking financial resources. It neither has alternative inner-city land available nor the political support to convert existing land uses so that slum dwellers 
may become property owners (see Kundu 2013). This can be seen in the case of the evicted slum noted above. Being a temple city, the respective actors are not inclined to let go of their inherited grip on land. ${ }^{21}$ In the light of the growing real-estate values in the temple and tourist city, this problem is not going to get any smaller. So when the SlumFree Cities Mission was discontinued in 2015, and the pilot project closed as non-starter, none of the identified beneficiaries had received land titles.

\section{Specificity of the temple and tourist city of Puri}

This leads to a few notes on Puri's historical specificity pertaining to land ownership and the formation of slums. Puri is a complex cultural entity of political and economic significance. For centuries, Puri has been conceptualised as the abode of Lord Jagannath, the "Lord of the Universe." The Cult of Jagannath, and therefore Puri, historically served to legitimise regional feudal kingdoms and played a great role in early state formation and the Hinduisation of Orissa's tribal societies (Eschmann, Kulke, and Tripathi 1978; Kulke 1980; Kulke and Schnepel 2001). In the current religio-political scenario, this role and significance of Puri and Jagannath become critical once again. As a result, the inherited political and institutional structures remain decisive elements in the particular urban situation of Puri (Véron 2010). This is particularly true when it comes to the question of who owns and controls land in the temple city today. This question is not only key to analysing contemporary urban development in Puri but also the formation and situation of "slums." Before discussing these issues, a short glimpse at the characteristics of the urban fabric of the temple city.

\section{Remarkable socio-spatial cohesion}

The urban fabric of Puri is characterized by a remarkable socio-spatial cohesion (Gupta and Gupta 2013). This feature is the product of the comparative stability of the inherited socio-economic structure tied to the temple. For centuries, Puri had a population of approximately 40,000 residents (Rösel 1980:5-6). These were predominantly of Deoli Brahmin origin: the Cult of Jagannath depended on the services of roughly ten thousand temple servants and their families known as pandas. ${ }^{22}$ Their residential quarters were organised around the temple and are locally known as sahis (Kulke 1980:35; Starza 1993:7). Their construction strictly followed the societal rules of the time. They were assigned to distinct groups of temple servants, which differed in terms of caste and function in the temple rituals (Rösel 1980:18-90; Rösel 1988; Kulke 1980:35-36). Religious and cultural practices were thus inscribed in Puri's territory over time. While in India, town planning and architecture often reflect "transcendental patterns of the primeval cosmic order," Puri serves as an example of the intrinsic relationship between religion, power, politics and medieval town planning (Kulke 1980:30).

Another factor contributing to Puri's historical socio-spatial cohesion is the fact that the god, and therefore the temple, has historically been conferred formal powers and thus has emerged as the largest land-owner in the region (Pasayat 2007:10; Rösel 1988; Kulke 1978). Substantial changes occurred with British colonial rule. The construction of the railway line was particularly decisive. It made "almost all of a sudden the whole of India and all social strata the potential market of the great lord" (Rösel 1980:XXVII; author's translation). Thereby, it led to previously unimaginable prosperity among the 
pandas. Formerly landless, they started to acquire land (Rösel 1980; Rösel 1988). Concurrently, the colonial practice of investment in community big-men and traditional authorities aided the concentration of power in the hands of those running the temple (Hansen 2005:184-5, in Gandhi 2012:57; Pasayat 2007). Therefore, it is possible to conclude that the British supported the formation of a power structure in which the temple servants and their relatives are key actors. The current chairperson of Puri Municipality for instance, an hotelier, belongs to the group of traditional guides for pilgrims (Rösel 1980). While the temple management committee still plays a significant role in all affairs, members of the committee are particularly influential (Pasayat 2007:6). This pertains especially to the conflict-laden question of land use and ownership in the temple and tourist city. ${ }^{23}$

\section{Control over land and "slum" formation}

It is difficult to assess the share of land directly owned or controlled by the temple in Puri today. ${ }^{24}$ It is clear that the town core with its historically residential and religiouscommercial use is predominantly composed of private property. The share of open spaces is continuously shrinking. Former temple gardens and agricultural land used by the temple is increasingly built up (SPA 2005; IPE Global 2016:256). While real-estate in Puri is still comparatively affordable, local sources stressed that land grabbing and illegal land transfers have been common over the past decades. Priest politicians and other "smart ones" with the right connections to the temple appear to be the key actors in the process of "developing" the temple city. ${ }^{25}$ In the process of Puri's urban transition, many thus "bought" land originally endowed to the temple without actually acquiring legal titles. ${ }^{26}$ The formation of "slums" in Puri hence has to be analysed in this particular situation. This is however beyond the scope of this paper (Hagn forthcoming).

Still, it is key to note that Puri's urban environment has always been marked by exclusion and segregation. The historical pattern of socio-spatial segregation was based on caste and the associated livelihood of caste-based communities in the temple economy. Poor communities that were historically underprivileged but "serve the temple" thus live in other locations than migrants who arrived in Puri later and work in the tourism-based economy. ${ }^{27}$ Forming part of the inherited socio-spatial fabric, they however often have tenure security. Many are land owners. Before the Slum-Free Cities Mission, they were notified $^{28}$ either as permanent or as encroachment slums. ${ }^{29}$ Therefore, they were privileged in accessing BSUP. By contrast, "new slums" typically were encroachment slums. Discriminated against as sites of illegality and crime, these "illegal" slums are notorious as the vote banks of the political leader in Puri. Especially towards the west of the town core, many slums formed on land historically used for agriculture and other socio-cultural purposes by Puri's temples and the numerous socio-cultural and religious community institutions (see IPE Global 2016:6, 256ff). Officially though, the majority is located on "unutilised government land" (SUIDL 2013:14).

The survey of slums for the Slum-Free Cities Mission identified, among the 62 eligible slums, four slums (at least partly) on matha (monastery) land; one on jagaghara (traditional sports club) land; 22 (at least partly) on municipal land; 20 on tahasil (Revenue Department) land; three (at least partly) on railway land; 17 (at least partly) on their own land; two (at least partly) on sweet water zone land (Public Health Department); and two on privately-owned land (SUIDL 2013:15ff). Ending this short introduction to the temple 
city here, the next section provides a glimpse into how the Mission has been localised in Puri.

\title{
4. Localisation of the Slum-Free Cities Mission
}

Somewhat confirming Kundu's analysis, the Slum-Free Cities Mission in Puri became a non-starter (2013:16). As I show in this section, it still, however, had substantial effects on the urban fabric. Compared to JNNURM, the Slum-Free Cities Mission reached far wider: targeting all slums, city wide, it marked a qualitative shift in slum re-development. Under JNNURM nine slums with tenure security, mostly Puri's "old bastis," were selected as project sites (Hagn forthcoming). Now, Puri's "new slums" were also addressed. As noted, the planning process lead to the categorisation of the neighbourhoods of about half of Puri's slum dwellers as untenable sites. Yet, in the end, the Mission failed; except for one part of the slum near Puri station, the physical conditions of all slums remained unchanged. Despite or due to the operational problems-a result of the regulatory ambiguity critiqued by Kundu (2013) and Roy (2014)?-the Mission merely served local political leaders to keep their vote banks in line. To show how, this section focuses on two elements. Both form part of the process of making a Slum-Free City Plan of Action, which is the central planning tool under the Mission (GOI 2011c): the list of eligible slums, and "RAY Management Committees."

\section{The list of eligible slums}

\begin{abstract}
Listing Slums: "Urban local bodies shall identify and list all slums in their city/town (currently authorised and unauthorised) and categorise them as per the slum typologies in the chart .... These lists will be developed with the help of satellite imagery and validated by site visits. The slum lists will be updated regularly till the backlog of slum upgrading, redevelopment and housing provision is over and there is housing available for all slum dwellers including new migrants" (GOO 2011:6).
\end{abstract}

In the process of slum-free city planning, the first step for the concerned urban local body is the identification and notification of eligible slums (GOO 2011:6). The Mission recognises all slums on all types of lands as long as these are formed of "at least 20 households" (GOI 2011b:3-5). To list and categorise Puri's eligible slums, the "City Level Technical Cell" (CLTC) at Puri Municipality worked together with a contracted "leadNGO" for community participation: Pragati (GOO 2011:17). Pragati has been working in Puri for many years, so they said they recognise when there are new slums, starting from 20 households. Apart from their own experience and observation, Pragati first consulted the ward councillors ${ }^{30}$ on new slums in their wards. They also consulted community leaders in existing (i.e. already listed) slums. In this way, they came up with a provisional list of eligible slums, which they handed over to Puri Municipality. By means of a council resolution-i.e. after discussion and negotiation in the town council-the list was finalised. Only those slums included in the final list were eligible for the Slum-Free Cities Mission. The 63 slums listed by Pragati in 2013 included the 46 slums listed before the Mission as well 17 "new" slums: New means that they had not been listed before (compare figure 1; SUIDL 2013). Unlike before, now, all listed slums were notified. 


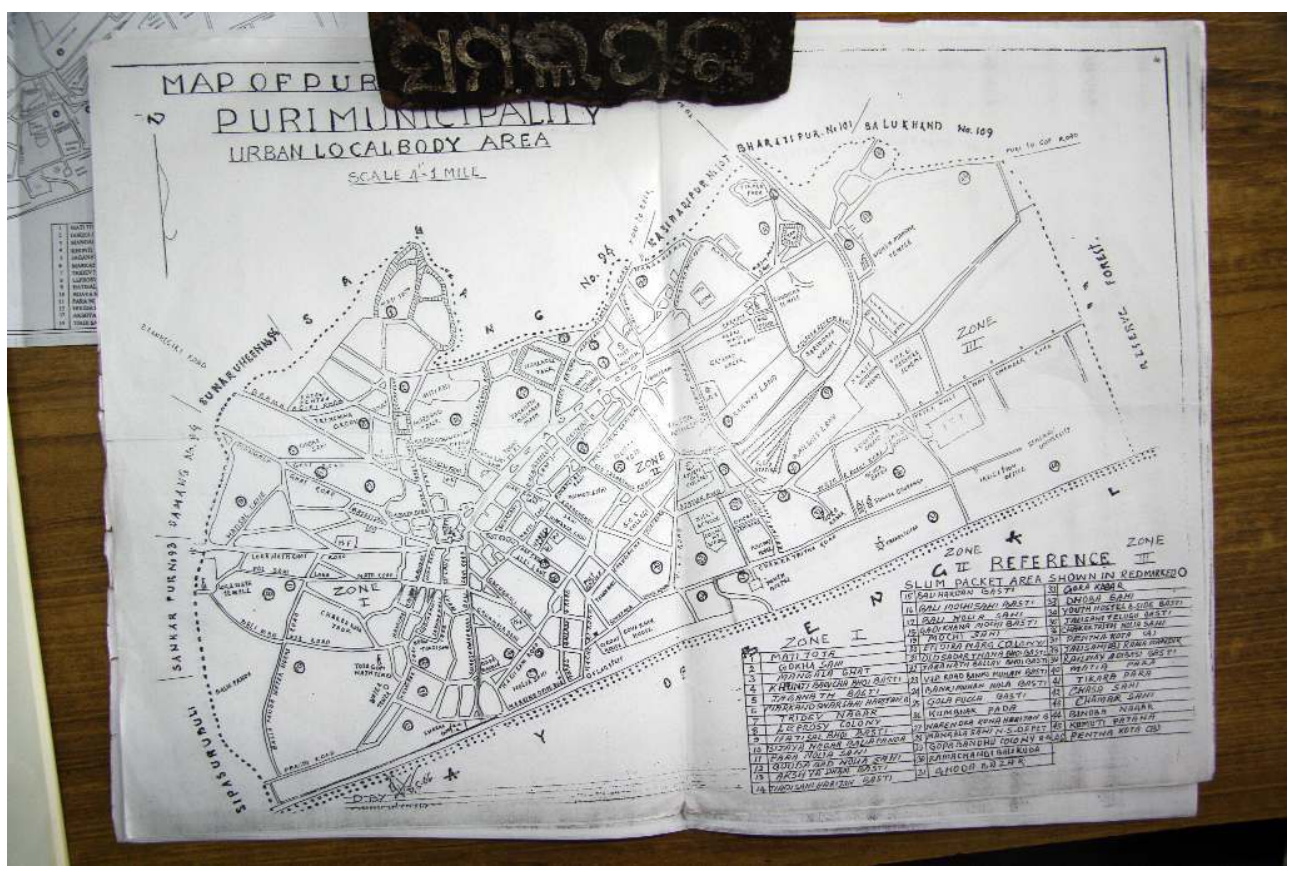

PHOTOgRAPH OF THE 2006 MAP OF SLUMS IN PURI (TAKEN BY THE AUTHOR IN MARCH 2011)

Taking into account the existing literature on slum listing, the list of eligible slums in Puri is not simply the product of a technical mapping exercise and of site visits of experts as suggested by the Mission guidelines (GOO 2011:6). It is the product of a deeply political process involving various intermediaries at slum, ward and city levels (Chattopadhyay 2015; de Wit and Berner 2009; Mitlin 2014; Raman 2015). While I did not have access to the complex and lengthy process of negotiation, cooperation and contestation during the listing of slums, I would like to draw attention to the particular role of the lead-NGO Pragati (Hull 2012).

Contracted by Puri Municipality to identify, mobilise and organise eligible slum dwellers, the NGO did not only take up the critical task of identifying rightful recipients for the state's resources. Due to the political nature of this task, it also faced the risk of becoming a political fixer in the local set-up of patronage politics (Berenschot 2014). Whether Pragati had the capacity (i.e. political influence) of advancing the cause of the poor and of challenging the local dynamics of patronage politics remains at least questionable from the data available to me (Mitlin 2014; Hagn forthcoming). In my interviews, Pragati staff avoided plain speaking on the political dimensions of their work.

What is clear is that Pragati, due to many years of implementing infrastructure-related schemes in Puri's slums, had established contacts both with community leaders and political actors. In other words, Pragati had a track record as intermediary between the formal and informal authorities: it had access both to the experts and bureaucrats as well as to "the power sector" ${ }^{31}$ in the slums. This is, in the situation of Puri, as critical as having "the right political connections" to implement social welfare or poverty alleviation schemes (Gandhi 2012; Patnaik and Patnaik 2006:133). Knowing that the list of eligible slums is the decisive first step to (potentially) access the Mission, local slum leaders thus also approached the NGO: 
Interviewer: What did you do to be on the list?

NGO worker: They [the residents] gave an application to me. I forwarded it to the executive officer. Being the lead-NGO for RAY, they requested me. Then I found that there are more than 20 families. And I forwarded their request to the executive officer. And it was passed in the municipal council, declared as a slum.

Interviewer: So the Colony, you, approached the NGO?

Residents: Yes.

Interviewer: And thereafter, you proposed it to the council.

NGO: Yes.

Georgiadou that slum listing is fundamentally an "organic practice" and opens up "channels of negotiation with city administration and politicians, which are vital for the poorer sections of the urban populace" (2016:75). However, while slum listing is potentially a valuable and highly-needed opportunity to promote the cause of the poor, this opportunity represents a tremendous burden on the involved NGO. Forming part of the "broader relations of power," it is centrally involved in deciding which slums and slum households are eligible (Raman 2015:373). Pragati thus found itself in the midst of complex conflicts of interests. Concurrently, it was caught up in a situation marked by mistrust among all actors, due to the scarcity of the benefit at stake. Both explain their scepticism towards the foreign researcher, myself. It was not clear to them on what side I was standing, politically. The political nature of organising communities for the Mission, and how it is entangled in local networks of power and patronage, became visible also in the second element of slum-free city planning discussed here.

\section{RAY Management Committees}

Once the list of eligible slums was accepted and sanctioned by the council, the process of "community organisation and motivation" had started. Pragati explained that they first invited the leaders of several (each time six to eight) adjacent slums to their office. In these meetings, they informed the leaders on the Mission, their prospects, and the process. Only with their support could they organise the required "general body meetings" in the listed communities (see also Patnaik and Patnaik 2006:133). In these meetings, Pragati then informed the residents and started to motivate local participation. They also coordinated slum-level organisations for community participation and inclusive planning, "RAY Management Committees." While I did not have access to these critical situations in the process of slum-free city planning, I spoke to several such committees later. 

the size of the slum, both female and male. While the NGO claimed that all households were present in the general-body meetings in the respective slums, several residents negated this. These meetings had taken place. However, it is to be doubted that all households participated or were represented (see also Richter and Georgiadou 2016:82). For example, one local activist told me that he had been at school. While their husbands are absent to work, many women would furthermore not leave the house. A local leader in another slum told me she did not join as she refused collaboration with Pragati. Whether or not all households were present in these meetings: to become a member of the committees requires not only a particular set of skills and knowledge but also the (economic) capacity to make time for participation. This situation excludes the poorest and privileges existing socio-political networks and political fixers (Björkman 2014:195).

In Baliapanda, so one resident, the members of the committee were not elected. "They are directly nominated" by the slum lord. "They even may have given money to ... [him] to become a member." In Ramachandi Balikuda, the slum that was evicted in October 2014, the ex-councillor is a significant local political figure. In all issues pertaining to the slum, he gets the work done (see also Björkman 2014). As Pragati staff explained during an interview with the committee in February 2013, "The ex-councillor, Mr. G. Mardaraj, is absolutely cooperative. They are meeting him frequently until today. He is looking after all the issues of the slum. Of the slum dwellers. There is a good relation between the slum dwellers and him." M. Mardaraj belongs to the ruling BJD party. Later, I learned that the committee's general secretary, Mr. Sadanand Pradhan, belonged to the ex-councillor's network: I met him in the office of the ex-councillor in December 2013, along with the newly elected standing councillor (BJD) and other supporters.

At this point in time, the group around Mr. Mardaraj was already concerned about the possibility of eviction from the site. They wanted me to "feel their problems. [Other man adding] Practical problems, which they are facing. When the platform of the station will be extended, they will face a lot of problems." While they were sympathetic to the concerned residents, they anticipated that they could actually do very little. Nevertheless, this meeting took place just before the general elections of 2014. Before leaving the office, they asked me not to talk about the threat of eviction with the residents.

The "real existing conditions to mobilise" for housing in Puri thus turned out to be marked by electoral politics (Rao Dhananka 2013). In other words, "clientelist bargaining prevails," in Puri, too (Mitlin 2014). None of the committees I spoke to had the ability to "make common cause with those in need across the city building a unified and aware movement" (Mitlin 2014). This situation caused substantial frustration to the Bhubaneswar based NGO UDRC, which had tried to establish a city-wide network of federations in Puri (Hagn forthcoming). Instead, the committees were formed by locals clearly linked to, or at least supporting, the existing local power structure. Their motivation was the hope for potential access to the Mission, based on their aspiration for proper housing and land titles (see also Anand and Rademacher 2011). This hope is weak. All slum dwellers know that, government schemes rarely outlive the pilot or first phase. ${ }^{33}$ Tasked with organising community participation, against their mistrust, Pragati thus requested that the different committees be faster than the others in achieving their mandatory, participatory tasks:

South Asia Multidisciplinary Academic Journal, 14 | 0000 
NGO worker: Has the process of assigning the houses numbers begun? Only two houses have been given numbers?

Woman 1: No.

NGO: Get the numbering done. Otherwise you will be in trouble. The old man [the MLA] will come tomorrow.

Woman 1: Tomorrow a hundred houses will be allotted numbers.

NGO: You should begin from one house and go on numbering other houses systematically. Giving numbers to hundred houses just like that won't help.

Thereby, Pragati became a decisive actor in the political orchestration of competition among slum-dwellers for access to the scarce and highly sought-after resources at stake.

\section{Conclusions}

The Slum-Free Cities Mission can be affirmed as a non-starter in Puri, especially with regard to the implementation of the sole pilot project. However, the Mission has had several important effects in its failure. It was the first planning exercise that categorised a large share of Puri's slums as "untenable." Thereby, it increased the level of insecurity and vulnerability of the concerned slum dwellers. Eviction is now a tangible possibility in Puri, too. The Mission further increased the benefit-at-stake: from funding for dwelling units of land-owning communities under BSUP to property rights and consolidated housing also for, until then, illegal encroachers. In other words, the Mission increased the value of the potential gifts of Puri's political patrons. The existing conditions for mobilising slum dwellers in Puri across ethnic, religious and caste boundaries were difficult already before the Mission. In the absence of "clear policy directives defining the ground rules" (Kundu 2013:16), the increased vulnerability of slum dwellers along with their new hopes and aspirations benefited only one group of actors: Puri's political leaders and fixers. As the Mission on the ground reinforced the ever-present competition for access to state resources, I argue that it (further) politicised the urban. In Puri, the Mission has been less about capturing valuable inner-city land for speculative urban development as in larger Mission cities. Instead, its poor operationalisation allowed local political leaders to use the flagship scheme in their political game. The scarcity of the promised benefit-in-offer, proper land titles and inner-city housing, turned out to be the carrot to "mobilise and organise" community participation while keeping voters in line.

\section{BIBLIOGRAPHY}

Anand, Nikhil and Anne Rademacher. 2011. "Housing in the Urban Age: Inequality and Aspiration in Mumbai." Antipode 43(5): 1748-72. doi: 10.1111/j.1467-8330.2011.00887.x.

Arabindoo, Pushpa. 2011. "Rhetoric of the 'Slum'." City 15(6): 636-46. doi: 10.1080/13604813.2011.609002.

Banerjee-Guha, Swapna. 2010. Accumulation by Dispossession: Transformative Cities in the New Global Order. Thousand Oaks, CA: Sage. 
Banerjee-Guha, Swapna. 2009. “Neoliberalising the 'Urban': New Geographies of Power and Injustice in Indian Cities.” Economic \& Political Weekly 44(22): 95-107.

Banerjee-Guha, Swapna. 2002. "Metropolitan Dominance and Regional Disparity in India: Observations from Relevant Planning Measures of Japan.” Pp. 61 in V.R.F. Series No. 358. Chiba: Institute of Developing Economies, Japan External Trade Organization.

Batra, Lalit. 2009. "A Review of Urbanisation and Urban Policy in Post-Independent India." Working Paper Series, Centre for the Study of Law and Governance, New Delhi: JNU.

Baviskar, Amita. 2012. "The Politics of Land and Citizenship." Presented at The 21st Century Indian City: Working Towards Being Slum Free?, University of California, Berkeley, CA. Retrieved August 12, 2013 (http://indiancities.berkeley.edu/2012/index.html).

Berenschot, Ward. 2014. “Political Fixers in India's Patronage Democracy.” Pp. 196-217 in Patronage as Politics in South Asia, edited by A. Piliavsky. Cambridge: Cambridge University Press.

Bhan, Gautam. 2009. “'This Is No Longer the City I Once Knew.' Evictions, the Urban Poor and the Right to the City in Millennial Delhi." Environment and Urbanization 21(1): 127-42. doi: 10.1177/0956247809103009.

Bhattacharyya, Sukanya. 2016. "Government Is Building Homes That the Poor Do Not Want." The Quint, New Delhi, June 24.

Björkman, Lisa. 2014. "Vote Banking as Politics in Mumbai." Pp. 176-96 in Patronage as Politics in South Asia, edited by A. Piliavsky. Cambridge: Cambridge University Press.

Bell, David and Mark Jayne. 2006. Small Cities: Urban Experience Beyond the Metropolis. Oxon, UK: Routledge.

Chattopadhyay, Soumyadip. 2015. "Contesting Inclusiveness: Policies, Politics and Processes of Participatory Urban Governance in Indian Cities." Progress in Development Studies 15(1): 22-36. doi: 10.1177/1464993414546969.

Coelho, Karen, T. Venkat and R. Chandrika. 2012. "The Spatial Reproduction of Urban Poverty: Labour and Livelihoods in a Slum Resettlement Colony." Economic \& Political Weekly 47 (47 \& 48): 53-63.

CMAO. 2006. "Puri City Development Plan. A Report by Puri Municipality, Housing \& Urban Development Department and City Managers' Association Orissa." Puri: Puri Municipality.

CRISIL Infrastructure Advisory. 2013. Rapid Baseline Assessment: Puri City Draft Report. Prepared for Ministry of Urban Development, Government of India, Capacity Building for Urban Development. Bhubaneswar: CRISIL Risk and Infrastructure Solutions Limited.

de Wit, Joop and Erhard Berner. 2009. "Progressive Patronage? Municipalities, Ngos, Cbos and the Limits to Slum Dwellers' Empowerment." Development and Change 40(5): 927-47.

Dubbudu, Rakesh. 2016. “96 Percent of Houses Constructed for Urban Poor Vacant in Delhi.” The Quint, New Delhi, May 12.

Dupont, Véronique. 2011. "The Dream of Delhi as a Global City." International Journal of Urban and Regional Research 35(5): 533-54. doi: 10.1111/j.1468-2427.2010.01027.x.

Eschmann, Anncharlott, Hermann Kulke and Gaya Charan Tripathi. 1978. The Cult of Jagannath and the Regional Tradition of Orissa. Vol. 8. New Delhi: Manohar.

Gandhi, Ajay. 2012. “'Informal Moral Economies' and Urban Governance in India.” Pp. 51-65 in Urban Informalities, edited by C. McFarlane and M. Waibel. Farnham: Ashgate. 
Ghertner, D. Asher. 2012. "Nuisance Talk and the Propriety of Property: Middle Class Discourses of a Slum-Free Delhi.” Antipode 44(4): 1161-87. doi: 10.1111/j.1467-8330.2011.00956.x.

Gilbert, Alan. 2009. "Extreme Thinking About Slums and Slum Dwellers: A Critique." SAIS Review 29(1): 35-48. doi: 10.1353/sais.0.0031.

Gilbert, Alan. 2007. “The Return of the Slum: Does Language Matter?” International Journal of Urban and Regional Research 31(4): 697-713. doi: 10.1111/j.1468-2427.2007.00754.x.

Goldman, Michael. 2011. "Speculative Urbanism and the Making of the Next World City." International Journal of Urban and Regional Research 35(3): 555-81. doi: 10.1111/

j.1468-2427.2010.01001.x.

Government of India. 2015. Office Memorandum: Discontinuation of Rajiv Awas Yojana (RAY) and Rajiv Rinn Yojana (RRY) \& Subsuming of Liabilities Created There-under in the New Mission on Housing for All by 2022- Reg. Retrieved April 6, 2016 (http://mhupa.gov.in/writereaddata/

Ray_Discontinuation_19_05_2015.pdf).

Government of India. 2013, "Conference Adopts Delhi Declaration on Inclusive Urban Planning." Delhi: Press Information Bureau, Government of India. Retrieved June 11, 2014 (http://pib.nic.in/ newsite/erelease.aspx?relid=92316).

Government of India. 2011a. Census of India 2011. Provisional Population Totals. Urban Agglomerations and Cities. Cities Having Population 1 Lakh and Above. Retrieved March 10, 2014 (http:// censusindia.gov.in/2011-prov-results/paper2/prov_results_paper2_indiavol2.html).

Government of India. 2011b. Rajiv Awas Yojana... Towards a Slum-Free India: Guidelines. New Delhi: Ministry of Housing \& Urban Poverty Alleviation. Retrieved October 8, 2013 (http:// mhupa.gov.in/ray/02-RAY-Guidelines.pdf).

Government of India. 2011c. Draft: Guidelines for Preparation of a Slum Free City Plan of Action Under the Rajiv Awas Yojana. New Delhi: Ministry of Housing \& Urban Poverty Alleviation, Government of India. Retrieved October 9, 2013 (http://mhupa.gov.in/ray/planning_guidelines.pdf).

Government of India. 2009. Rajiv Awas Yojana: Guidelines for Slum-Free City Planning. New Delhi: Ministry of Housing \& Urban Poverty Alleviation, Government of India. Retrieved June 15, 2010 (http://indiagovernance.gov.in/files/RAY-guidelines.pdf).

Government of Odisha. 2014. In-situ Upgradation of Slum at Tridev Nagar, Puri. Presented before the CSMC, November 11. Retrieved April 17, 2015 (http://mhupa.gov.in/ray/ csmc_ppt/11th_CSMC_Puri.pdf).

Government of Odisha. 2012. The Odisha Property Rights to Slum Dwellers and Prevention of New Slums Bill, 2012. Retrieved June 3, 2014 (http://www.urbanodisha.gov.in/(S

(mmsysc45j1g52d55er0ffn45))/pdf/

ODISHA_PROPERTY_RIGHTS_TO_SLUM_DWELLERS_BILL_2012.pdf).

Government of Odisha. 2011. Housing for All: Slum Rehabilitation \& Development Policy (SRDP) for Orissa. Retrieved November 8, 2012 (http://orissa.gov.in/govtpress/pdf/2011/442.pdf).

Gooptu, Nandini. 2001. The Politics of the Urban Poor in Early Twentieth-Century India. Vol. 8. Cambridge: Cambridge University Press.

Gupta, Archana and Anshuman Gupta. 2013. "Puri at the Centre of Its Universe." IFLA Newsletter 105: 3-6.

Hagn, Andrea. Forthcoming. "Politicising the Urban: The Politics of Slum Re-development in the Temple City of Puri, Odisha.” PhD Dissertation, ETH Zürich. 
Hardy, Adam. 1999. "Birabalabhadrapur: A Brahmin Village in Orissa." South Asian Studies 15(1): 67-83. doi: 10.1080/02666030.1999.9628567.

Home, Robert. 1997. Of Planting and Planning: The Making of British Colonial Cities, G. E. Cherry and A. Sutcliffe, eds. London: E. \& F.N. Spon.

Huchzermeyer, Marie. 2014. “Troubling Continuities: Use and Utility of the Term 'Slum'." Pp. 8697 in The Routledge Handbook on Cities of the Global South, edited by S. Oldfield and S. Parnell. London and New York: Routledge.

Hull, Matthew S. 2012. Government of Paper: The Materiality of Bureaucracy in Urban Pakistan. Berkeley: University of California Press.

IPE Global Private Limited and CRCI India Private Limited. 2016. City HRIDAY Plan for Puri. Vol. I of IV. Prepared for National Institute of Urban Affairs and Ministry of Urban Development. Retrieved May 31, 2016 (http://hridayindia.in/downloads/chp/puri/CHP_for_Puri_Volume_I.pdf ) .

Jones, Branwen Gruffydd. 2012. “'Bankable Slums': The Global Politics of Slum Upgrading.” Third World Quarterly 33(5): 769-89. doi: 10.1080/01436597.2012.679027.

Knox, Paul L. 2009. “Urbanization.” Pp. 112-18 in International Encyclopedia of Human Geography, Vol. 1, edited by R. Kitchin and N. Thrift. Oxford: Elsevier.

Kulke, Hermann and Burkhard Schnepel. 2001. Jagannath Revisited: Studying Society, Religion and the State in Orissa. Vol. 1, Jagannath Revisited, edited by H. Kulke and B. Schnepel. New Delhi: Manohar. Kulke, Hermann. 1980. "Legitimation and Town-Planning in the Feudatory States of Central Orissa." Pp. 30-40 in Ritual Space in India: Studies in Architectural Anthropology, Art and Archaeology Research Papers, edited by J. Pieper. London: Coach Publishing.

Kulke, Hermann. 1978. “Jagannatha as the State Deity under the Gajapatis of Orissa.” Pp. 199-208 in The Cult of Jagannath and the Regional Tradition of Orissa, edited by A. Eschmann, H. Kulke, and G. C. Tripathi. New Delhi: Manohar.

Kundu, Amitabh. 2013. “Making Indian Cities Slum-Free.” Economic \& Political Weekly 48(17): 15-18. Kundu, Amitabh. 2001. "Urban Development, Infrastructure Financing and Emerging System of Governance in India: A Perspective.” Discussion Paper No. 48, Management of Social Transformations (MOST), Geneva, UNESCO.

Mathur, Om Prakash. 2009. "The National Urban Poverty Reduction Strategy 2010-2020: SlumFree Cities-a New Deal for the Urban Poor.” New Delhi: NIPFP.

McKinsey Global Institute. 2010. India's Urban Awakening: Building Inclusive Cities, Sustaining Economic Growth. McKinsey \& Company. Retrieved June 21, 2010 (http://www.mckinsey.com/ $\mathrm{mgi} /$ publications/india_urbanization/index.asp).

Mitlin, Diana. 2014. "Politics, Informality and Clientelism: Exploring a Pro-Poor Urban Politics." Working Paper No. 34, Effective States and Inclusive Development Research Centre, Manchester.

Patnaik, Pramila Prava and Karunakar Patnaik. 2006. Provisions of Basic Services in Bhubaneswar Municipal Corporation and Puri Municipality: A Situational Analysis. Bhubaneswar: Institute of Social Sciences.

Pasayat, Chitrasen. 2007. “Landed Property of Lord Jagannath.” Orissa Review, June-July 2007, pp. 5-17.

Puri Municipality. 2009. Detailed Project Report: 24/7 Piped Water Supply for Puri City. Volume I: Report. Retrieved March 5, 2014 (http://urbanorissa.gov.in/pdf/document/puri_vol_I.pdf). 
Raman, Bhuvaneswari. 2015. “The Politics of Property in Land: New Planning Instruments, Law and Popular Groups in Delhi." Journal of South Asian Development 10(3): 369-95. doi: 10.1177/0973174115610186.

Rao, Ursula. 2010. "Making the Global City: Urban Citizenship at the Margins of Delhi." ethnos 75 (4): 402-24. doi: 10.1080/00141844.2010.532227.

Rao Dhananka, Swetha. 2013. "Of Housing and Politics: Mapping Political Opportunities for Mobilising in Bangalore, India." PhD dissertation, Faculté des sciences sociales et politiques, Université de Lausanne.

Richter, Christine and Yola Georgiadou. 2016. "Practices of Legibility Making in Indian Cities: Property Mapping through Geographic Information Systems and Slum Listing in Government Schemes." Information Technology for Development 22(1): 75-93. doi: 10.1080/02681102.2014.886548.

Risbud, Neelima. 2009. “The Poor and the Morphology of Cities.” Pp. 177-98 in India: Urban Poverty Report, edited by UNDP and MHUPA. New Delhi: Oxford University Press.

Rösel, Jakob. 1988. Tempelstadt Puri: Pilger und Priester am Hofe des Jagannath. Freiburg i. Br.: Hedwig Falk.

Rösel, Jakob. 1980. Der Palast des Herrn der Welt: Entstehungsgeschichte und Organisation der Indischen Tempel- und Pilgerstadt Puri. Munich, London: Weltforum Verlag.

Routray, Jayant Kumar and A. K. Pradhan. 1989. "Slums and Development Programmes in Eastern India: A Case Study of Cuttack City.” Habitat International 13(4): 99-108.

Roy, Ananya. 2014. "Slum-Free Cities of the Asian Century: Postcolonial Government and the Project of Inclusive Growth.” Singapore Journal of Tropical Geography 35(2014): 136-50.

Roy, Ananya. 2011a. "The Blockade of the World-Class City: Dialectical Images of Indian Urbanism." Pp. 259-78 in Worlding Cities: Asian Experiments and the Art of Being Global, edited by A. Roy and A. Ong. Chichester: Wiley Blackwell.

Roy, Ananya. 2011b. "Slumdog Cities: Rethinking Subaltern Urbanism." International Journal of Urban and Regional Research 35(2): 223-38. doi: DOI:10.1111/j.1468-2427.2011.01051.x.

Roy, Ananya. 2010. Poverty Capital: Microfinance and the Making of Development. New York: Routledge.

Roy, Ananya. 2003. City Requiem Calcutta: Gender and the Politics of Poverty. Minneapolis: University of Minnesota Press.

Sahoo, Niranjan. 2016. "India's Urbanisation Is Dangerously Exclusionary and Unequal." The Wire, Washington, DC, May 5.

Seabrook, Jeremy. 2009. "Myths of Victorian Squalor.” in The Guardian, London, July 12.

Selja, Kumari. 2011. "Ray Inaugural Address." Speech at the Conference of State Ministers on Rajiv Awas Yojana, July 30, 2011, New Delhi.

Sivaramakrishnan, K. C. 2012. "Slum Free Cities: A Pronouncement or a Policy?" Presented at the The 21st Century Indian City: Working Towards Being Slum Free?, University of California, Berkeley, CA. Retrieved August 12, 2013 (http://indiancities.berkeley.edu/2012/index.html).

SPA. 2005. Eco-City Development Plan for Puri Orissa. New Delhi: School of Planning \& Architecture.

Starza, Oleg M. 1993. The Jagannatha Temple at Puri: Its Architecture, Art, and Cult. Vol. 15. Leiden, New York, Cologne: E. J. Brill. 
SUIDL. 2013. RAY, Pilot Project: In-Situ Upgradation of Tridev Nagar. Detailed Project Report (Final), Volume I: Report for Puri Municipality. New Delhi: Shristi Urban Infrastructure Development Ltd.

Surjan, Akhilesh Kumar and Rajib Shaw. 2008. “"Eco-City' to 'Disaster-Resilient Eco-Community': A Concerted Approach in the Coastal City of Puri, India." Sustainability Science 3: 249-65. doi: 10.1007/s11625-008-0051-3.

Tawa Lama-Rewal, Stéphanie and Marie-Hélène Zérah. 2011. "Introduction. Urban Democracy: A South Asian Perspective.” South Asia Multidisciplinary Academic Journal 5. doi: 10.4000/samaj.3188.

UNFPA. 2007. "State of World Population 2007: Unleashing the Potential of Urban Growth." New York, N.Y.: United Nations Population Fund.

Véron, René. 2010. "Small Cities, Neoliberal Governance and Sustainable Development in the Global South: A Conceptual Framework and Research Agenda." Sustainability 2: 2833-48. doi: 10.3390/su2092833.

Young, Holly. 2011. "Restless Cities: How Are We to Understand the Meaning of Slums in Mumbai?" M Sc Contemporary India Dissertation, Contemporary South Asian Studies, University of Oxford, Oxford.

\section{NOTES}

1. Smaller cities are understood to be those urban areas with a population of less than 500,000 residents (UNFPA 2007).

2. Among the 63 selected cities were sixteen cities with a population of below 500,000 , four of which had less than 100,000 inhabitants.

3. "A RAY of hope for slum-dwellers in State." The Hindu, Bhubaneswar (2011).

4. The interviews involved slum dwellers, social workers, NGO staff, local politicians and their coworkers, municipal officers, the RAY cell at Puri Municipality, the JNNURM Project Management Unit at the Housing \& Urban Development Department, as well as other representatives of the Government of India and of Odisha. As I do not speak Odia, I worked with translators and audio recordings.

5. "Building Inclusive Cities." The Hindu, Delhi (2013).

6. Initiated by the Ministry of Environment and Forests under the Tenth Plan, it was implemented through the Central Pollution Control Board. It received technical support through German Technical Cooperation.

7. JNNURM had two main components. The Ministry of Urban Development directed the SubMission for Urban Infrastructure and Governance (UIG). The Ministry of Urban Employment and Poverty Alleviation (later: Ministry of Housing and Urban Poverty Alleviation) lead the SubMission for Basic Services to the Urban Poor.

8. "Odisha's poor show in projects under JNNURM." The Hindu, Delhi (2014).

9. Das, Prafula. 2015. “The Rebirth in Puri." Frontline, March 6.

10. "Odisha Nabakalebara: Two days before Rath Yatra, Puri in a mess." Odisha Sun Times (2015).

11. "Squatters ousted from Puri slum." The Telegraph, Kolkata (2014). Similarly, "Slum Dwellers Evicted From Near Puri RLY Station." The Pioneer (2014). "Eviction drive launched for Puri Rly Station Expansion." The New Indian Express, Bhubaneswar (2014).

12. "NHRC orders for Odisha slum dwellers' rehabilitation." Orissa Diary (2016).

13. "Centre stops JNNURM aid to Odisha." Odisha Sun Times (2015). 
14. "Puri enters Centre's 'Hriday' - Rs 22 crore for pilgrim city to develop infrastructure." The Telegraph, Kolkata (2015). For details on the planned investment under JNNURM, see CMAO (2006: 192).

15. "A RAY of hope for slum-dwellers in State." The Hindu, (2011).

16. "Centre orders revision of list of beneficiary slums." The Times of India (2011).

17. RSI Remote Sensing Instruments, Hyderabad; BISWA.

18. The "City Base Map of Puri, Odisha," received from Puri Municipality in November 2013, was clearly incomplete and inaccurate. Neither were all slums mapped nor were the mapped slums represented correctly.

19. SUIDL (2013:14) lists 47,530 slum dwellers in 8,897 households in 62 eligible slums in Puri. It is important to note that these figures constantly change, including in the same document, reflecting the political nature of "slum statistics." CRISIL (2013:13) suggests a number of 88,624 slum dwellers, which represents a share of $44 \%$ of the population. Pragati listed 63 slums as eligible and seven that did not qualify (see section 4 ).

20. As per Puri Municipality list, accessed by the author in 2011.

21. See e.g. "Land property rights crucial in Puri poll: Occupants unhappy over row in constituency." The Telegraph (2014). Or "Murder joins the long list of cases against the Jagannath temple of Puri priests." The Indian Express (2012).

22. Originally, these were landless, "degraded" Brahmins, with a comparatively low social status, controlled by elite Brahmin classes known as pandits. Of Vedic Brahmin genealogy, the latter received land and sinecure from the kings of Orissa to remain near Puri in their own socio-spatial enclaves (G. Pfeffer, in: Eschmann, Kulke and Tripathi 1978:421ff). Both groups were actually brought to Puri from Northern India.

23. See e.g. "Murder joins the long list of cases against the Jagannath temple of Puri priests." The Indian Express, Bhubaneswar (2012).

24. See however Pasayat 2007 for the landed estates of Jagannath outside Puri.

25. See also "Maheswar Mohanty ko Gussa Kyon Aata Hai?" Odisha Sunday Times (2015).

26. See again "Land property rights crucial in Puri poll: Occupants unhappy over row in constituency." The Telegraph (2014).

27. In Odisha, traditionally socially under-privileged and poor communities typically live in segregated neighbourhoods at the outskirts of villages (see Hardy 1999). Routray and Pradhan (1989) find similar patterns in Cuttack.

28. Notified slums are those informal settlements of the poor that are formally recognised by the urban local body by means of a town council resolution, i.e. slum notification. Notified slums have some sort of tenure security.

29. Before the Slum-Free Cities Mission, Puri Municipality differentiated between notified and non-authorised, i.e. illegal slums. Notified slums were either listed as permanent slums or as encroachment slums depending on the type of land occupied. Encroachment slums may be located on public land, e.g. on roads. Both in permanent and encroachment slums, there may be some structure owners with patta (record of rights). In 2001, Puri listed 26 notified slums (15 permanent and 11 encroachment slums) and 20 more non-authorised (illegal) slums.

30. The elected representatives of the different wards of Puri Municipality.

31. The power sector, so a local social worker, comprises community leaders, anganwadi workers, self-help group presidents, religious leaders, caste elders, political workers and other political leaders, councillors and ex-councillors.

32. I do not include this map here as I do not have the consent of Pragati, as of now. The information on Manibaba Colony stems from: interview transcript; list of encroached slum areas, 2001; list of eligible slums, prepared by Pragati in 2013; draft Puri City Base Map, prepared by RSI Remote Sensing Instruments, Hyderabad. 
33. While this discourse reflects the mistrust towards the state, it is also a fact that many central schemes require too much time to get going. If a scheme requires legal reforms, for instance, these may be on hold pending state-level elections. Before required bills are passed, the central government may have changed, as a high-ranking IAS officer stated to me in 2015. 